KOŚCIÓŁ I PRAWO 9(22) 2020, nr 2, s. 69-81

DOI: http://dx.doi.org/10.18290/kip2092-5

\author{
Wojciech Potocki
}

\title{
PÓŹNE POWOŁANIA KAPŁAŃSKIE \\ W KODEKSIE PRAWA KANONICZNEGO Z 1983 ROKU I PARTYKULARNYM PRAWIE POLSKIM
}

Zanim kandydat do stanu duchownego rozpocznie formację $\mathrm{w}$ seminarium duchownym najpierw musi zaistnieć czynnik powołaniowy. Obecnie liczba powołań jest zbyt mała w porównaniu do potrzeb duszpasterskich. Problem ten można zauważyć nie tylko na niektórych terenach pierwszej ewangelizacji, lecz również $\mathrm{w}$ wielu krajach o długiej tradycji chrześcijańskiej. W wielu wypadkach sytuacja staje się dramatyczna do tego stopnia, że zachodzi konieczność likwidowania parafii, zamykania kościołów, a nawet ich sprzedawania i wykorzystywania na inne cele. Często można usłyszeć o „kryzysie powołań”, jednak bardziej adekwatne wydaje się być sformułowanie „spadek powołań, ponieważ poza pewnymi oczywistymi problemami wewnątrzkościelnymi, problemami z religijnością młodzieży, mamy do czynienia również z czynnikiem demograficznym.

Formacja do kapłaństwa jest zasadniczo skierowana do młodzieńców, którzy zgłaszają się do seminarium duchownego, aby rozpocząć formację. Ustawodawca w kan. $235 \S 1$ Kodeksu Prawa Kanonicznego z 1983 r. ${ }^{1}$ wskazał, że młodzieńcy zamierzający dojść do kapłaństwa, powinni dla otrzymania odpowiedniej formacji duchowej oraz przygotowania się do właściwych im obowiązków, kształcić się w wyższym seminarium przez

DR WoJCIECH PотосKI - Sąd Okręgowy w Warszawie; e-mail: wojciech.b.potocki@ gmail.com; https://orcid.org/0000-0002-9390-6519

${ }^{1}$ Codex Iuris Canonici auctoritate Ioannis Pauli PP. II promulgatus (25.01.1983), AAS 75 (1983), pars II, s. 1-317; tekst polski: Kodeks Prawa Kanonicznego, przekład polski zatwierdzony przez Konferencję Episkopatu, Pallottinum, Poznań 1984. 
cały okres formacji. Należy zatem zapytać, jak będzie wyglądała formacja mężczyzn, którzy odkrywają dar powołania w wieku późniejszym oraz gdzie będzie ona przebiegać?

Celem niniejszego artykułu będzie przedstawienie, czym są tzw. powołania dojrzałe i co je różni od innych powołań, jaką formację ustawodawca przygotował dla kandydatów do kapłaństwa, którzy nie są już młodzieńcami, a także, jak przepisy partykularnego prawa polskiego regulują formację dojrzałych mężczyzn zgłaszających się do seminarium duchownego. W artykule zostanie przedstawiona instytucja Ogólnopolskiego Seminarium dla Starszych Kandydatów do Święceń zwanego „Seminarium 35+", które znajduje się w Łodzi.

\section{POWOŁANIE DO KAPŁAŃSTWA}

W polskim brzmieniu termin „powołanie” oznacza skłonności, uzdolnienia lub predyspozycje określonej osoby do wykonywania konkretnego zajęcia czy zawodu [Postawa 2005, 93]. Samemu pojęciu słowa „powołanie”, jako wyjątkowemu i osobowemu wezwaniu człowieka przez Boga do wypełniania posługi religijnej, nie została nadana legalna definicja w Kościele, a niemal zawsze ujmowano je od strony praktycznej [Baniak 2012, 33].

W Piśmie Świętym powołanie (gr. klesis, kalein; łac. vocatio, vocare) wskazywane jest jako fakt religijny pochodzenia nadprzyrodzonego, w którym Bóg wzywa człowieka do bliższego z nim współdziałania w ramach ekonomii zbawienia, zawartej w dziele stworzenia i odkupienia [Wosiński 1967, 29-30].

Powołanie do kapłaństwa jest darem, który Bóg daje Kościołowi i światu oraz drogą do uświęcenia siebie i innych. Nie może być ono przeżywane w sposób indywidualistyczny, lecz zawsze w odniesieniu do jakiejś konkretnej części Ludu Bożego². Powołanie do kapłaństwa jest częścią szerszego zakresu powołania chrześcijańskiego. „Każdy z nas jest powołany

\footnotetext{
${ }^{2}$ Congregazione per il Clero, Il Dono della vocazione sacerdotale. Ratio Fundamentalis Institutionis Sacerdotalis, Libreria Editrice Vaticana, Città del Vaticano 2016; tekst polski: Kongregacja ds. Duchowieństwa, Dar powołania do kapłaństwa. Ratio fundamentalis institutionis sacerdotalis, Watykan, 8 grudnia 2016 r. [dalej cyt.: RFIS], nr 3.
} 
przez nasz chrzest i potwierdzenie, aby odgrywać wyjątkową rolę w dziele Chrystusa i Jego Kościoła"3.

W każdym powołaniu działają trzy czynniki: działanie Ducha Świętego, który oddziałuje w kandydacie, formator, który kształtuje kandydata oraz sam kandydat [Tahhan 2018, 134].

Źródłem powołania jest Chrystus, który jest pełnią, źródłem i pierwowzorem wszystkich powołań, zwłaszcza zaś powołania do służby kapłańskiej, jako szczególnego uczestnictwa w Jego kapłaństwie [Pastewski 2015, 80]. Jezus zaprasza pierwszych uczniów do pójścia za nim i naśladowania go, aby mogli doświadczyć, kim On jest. Mówi do swoich uczniów, którzy nieśmiało próbowali już iść za nim „chodźcie a zobaczycie” [Hałas 2014, 13]. Uczeń pozostawia wszystko, aby odnaleźć również wszystko, ale przy Jezusie, który go powołał. Opuszczenie, które jest wyrazem pójścia za Jezusem, jest wyrazem posłuszeństwa i ma być pełnieniem woli Bożej aż do krzyża włącznie [Haręzga 1994, 87]. Współdziałania z łaską powołania Bóg oczekuje przede wszystkim od samego powołanego, aby nie pozostawał głuchy na głos wołania Bożego [Latusek 1967, 41].

Papież Jan Paweł II określił powołanie jako Boży dar stanowiący wielkie dobro dla tego, dla kogo jest wszystkim przeznaczone, jak również dar dla całego Kościoła, dobro dla jego życia i misji. Dlatego Kościół powinien chronić ten dar, cenić go i miłować ${ }^{4}$. Z kolei w liście do wszystkich Kapłanów Kościoła na Wielki Czwartek Ojciec Święty wskazał, że powołanie to przede wszystkim bycie człowiekiem, stawanie się człowiekiem bez względu na to, jaką formę drogi życiowej się wybierze ${ }^{5}$.

Początków powołania należy zawsze szukać w miłości i wolnej woli Boga. Powołanie jest łaską. Jezus powiedział do apostołów: „Nie wyście mnie wybrali, ale ja was wybrałem i przeznaczyłem was na to abyście szli i owoc przynosili i by owoc wasz trwał" (J 16,16). Bóg zaprasza powołanego do życia i posługi kapłańskiej, ale go nie zniewala, pozostawia mu wolną decyzję. Bóg nie daje Kościołowi gotowych kapłanów, składa jednak

\footnotetext{
${ }^{3}$ Programme for the Formation of Priests in Irish Seminaries, Irish Bishops Conference, Dublin 2006, s. 21.

${ }^{4}$ Ioannes Paulus PP. II, Adhortatio apostolica de sacerdotum formatione in aetatis nostrae rerum condicione Pastores dabo vobis (25.03.1992), AAS 84 (1992), s. 657-804; tekst polski w: Adhortacje apostolskie Ojca świętego Jana Pawła II, t. I (1979-1995), red. M. Romanek, Wydawnictwo Znak, Kraków 2006, s. 525-697 [dalej cyt.: PDV], nr 41.

${ }^{5}$ Tenże, List do kapłanów na Wielki Czwartek 1996 (17.03.1996), https://ekai.pl/ dokumenty/list-do-kaplanow-na-wielki-czwartek-1996/ [dostęp: 30.10.2020].
} 
w serca wybranych ziarno powołania, którego przyjęcie, rozwijanie i owocowanie zależy od współdziałania powołanego oraz całego Ludu Bożego [tamże, 40]. Powołanie jest talentem udzielonym przez Boga z równoczesnym wezwaniem do współdziałania z Nim. To współdziałanie z łaską wyraża się przede wszystkim w budzeniu, pielęgnowaniu i rozwijaniu.

Sam proces powołania uczniów był czymś niecodziennym. W tamtym czasie nauczyciele nie szukali sobie uczniów, to uczniowie szukali nauczyciela. Ponadto Jezus zrywa z tradycją jeszcze na jednej płaszczyźnie. Nie nakazuje Piotrowi i Andrzejowi, by osiedli się w określonym miejscu jako Jego uczniowie, lecz wskazał, że mają być nieustannie w drodze, słowa „chodźcie za Mną” należy rozumieć również fizycznie [Martin 2015, 156].

Chrystus przygotowywał Apostołów do głoszenia Dobrej Nowiny. Im właśnie w sposób szczególny, w odosobnieniu wyjaśniał Ewangelię (Mk $3,34)$ i zaprosił ich do przeżywania z Nim najważniejszych momentów historii zbawienia, która dokonywała się na ich oczach [Gałązka 2008, 273].

\section{POWOŁANIA DOJRZAŁE}

Do seminarium zgłaszają się różni kandydaci. Czasem już rozeznali, a niekiedy jeszcze rozeznają swoją drogę. Niektórzy z nich przychodzą po studiach, często mają doświadczenie pracy zawodowej. Jest to jasny znak tego, że Bóg nie ma względu na osoby, ale bardziej istotna jest wiara i posłuszeństwo Jego Słowu. Noe miał 600 lat, kiedy Bóg powołał go, aby zbawił resztkę ludzkości. Abraham miał 100 lat, kiedy Bóg powiedział mu, że będzie ojcem. Mojżesz miał 80 lat, kiedy stanął do walki z faraonem. Zachariasz i jego żona byli w podeszłym wieku, kiedy zostali rodzicami Jana Chrzciciela ${ }^{6}$.

Formacja do kapłaństwa jest zasadniczo skierowana do młodzieńców (iuvenes), wynika to wprost z treści kan. $235 \S 1$. Jednak ustawodawca zobowiązał biskupów diecezjalnych oraz kapłanów w kan. 233 § 2 o zatroszczenie się o mężczyzn w dojrzałym wieku przekonanych o powołaniu do świętej posługi [Jakubiak 2014, 94].

\footnotetext{
${ }^{6}$ How to Know If You're Too Old for Seminary, http://collegeandseminary.com/ seminary/know-youre-old-seminary/ [dostęp: 13.03.2020].
} 
Obecnie młodzież potrzebuje więcej czasu, żeby podejmować ważne życiowe decyzje. Dotyczy to powołania kapłańskiego, ale także zawarcia małżeństwa, założenia rodziny [Starzak 2013]. Formalnie nie ma żadnej granicy wiekowej dla kandydatów do kapłaństwa przyjmowanych do seminarium duchownego. Aktualnie coraz częściej zdarza się, że do seminariów duchownych zgłaszają się kandydaci w wieku 30-40 lat i starsi, którzy rezygnują z kariery zawodowej lub naukowej po odkryciu daru powołania. Mężczyźni odkrywający powołanie do kapłaństwa w wieku późniejszym prezentują bardziej uporządkowaną osobowość oraz historię życia, która jest naznaczona różnymi doświadczeniami (RFIS 24; PDV 61). W ocenie D. Cito jako kryterium rozróżnienia powołań należy wskazać nie wiek, ale ludzką kondycję kandydata. Późne powołania wymagają doboru odpowiedniej ścieżki formacji, która nie musi zbiegać się ze ścieżką formacyjną wyższego seminarium [Cito 2004, 220].

Najobszerniej koncepcja tzw. dojrzałych powołań została przedstawiona w liście okólnym z 14 lipca 1976 r. Vocationes adultorum ${ }^{7}$. Zaliczono do nich te, które nie mieszczą się w pojęciu tzw. normalnego powołania czy ścieżki edukacyjnej do kapłaństwa. Zdaniem dykasterii, późne powołania są potrzebne, szczególnie mając na uwadze ciągły spadek powołań. Jednocześnie podkreślono potrzebę większej ostrożności i roztropności przy rozeznawaniu powołania ze względu na wiek oraz osobiste i socjalno-kulturowe uwarunkowania kandydata.

Papież Jan Paweł II zwrócił uwagę na zjawisko powołań, które zostają odkryte w wieku dojrzałym, a nie w młodzieńczym. Zaznaczył, że nie jest to zjawisko nowe, ale znane wcześniej w Kościele, a w ostatnich czasach coraz częściej występujące (PDV 64). Biskup Rzymu wskazał, że nie zawsze jest możliwe, a często nawet niewskazane, ażeby dorośli przechodzili całą formację wyższego seminarium. Po dokładnym zbadaniu autentyczności tego rodzaju powołań należy opracować odpowiedni dla nich program formacji, zapewniający im niezbędne przygotowanie duchowe i intelektualne (PDV 64).

\footnotetext{
${ }^{7}$ Sacra Congregatio pro Institutione Catholica, Litterae circulares de criteriis praxique hodie sequendis in vocationibus adultorum ad sacerdotium curandis et instituendis Vocationes adultorum (14.07.1976), w: Leges Ecclesiae post Codicem iuris canonici editae. Collegit, digessit notisque ornavit Xaverius Ochoa in Universitate Lateranensi Professor, t. V: Leges annis 1973-1978 editae, Institutum Iuridicum Claretianum-Commentarium pro Religiosis, Roma 1980, nr 4459, kol. 7218-222.
} 
Opieka i formacja późnych powołań powinna harmonijnie uzupełniać aktualną dyscyplinę, a nie ją osłabiać lub znosić. Formacja powinna odbywać się w specjalnie do tego powołanym seminarium lub w wyższym seminarium, lecz według specjalnego programu przystosowanego do indywidualnych przypadków. Niewątpliwie przebywanie w jednym domu seminarzystów w różnym wieku daje możliwość dzielenia się przez starszych swoimi doświadczeniami duchowymi i apostolskimi z pozostałymi seminarzystami.

Tworzenie specjalnych seminariów dla późniejszych powołań jest rozwiązaniem optymalnym wobec poruszanego zagadnienia. Zdecydowanie łatwiejszym jest formowanie tzw. „starszego kandydata” w oparciu o jednolite i sprawdzone zasady obowiązujące w danym kraju, niż przygotowywanie indywidualnego procesu formacji dla każdego zgłaszającego się kandydata [Jakubiak 2014, 109-10]. Podmiotem właściwym do wydania stosownych norm uwzględniających uwarunkowania i sytuacje $\mathrm{w}$ danym kraju co do górnej granicy wieku przy przyjmowaniu takich kandydatów, ich formacji oraz w kwestii erygowania przeznaczonego dla nich odpowiedniego seminarium jest konferencja biskupów (RFIS 24).

Należy wskazać, że seminarium dla starszych kandydatów do święceń nie jest próbą zasilenia gwałtownie topniejących szeregów kapłańskich, lecz odpowiedzią na jeden ze znaków czasu, jakim jest wzrastająca liczba tzw. „późnych powołań”, a które ze względu na wiek domagają się odrębnego toku formacji. Patrząc w perspektywie globalnej widać coraz większą liczbę późniejszych powołań. W dzisiejszych czasach Kościół Chrystusowy może bardziej niż kiedykolwiek potrzebuje statecznych kapłanów o dużym doświadczeniu życiowym, poczuciu misji swojego życia i bezgranicznie odpowiedzialnych za zbawienie swoje i innych [Bielas 2019].

\section{POWOŁANIA DOJRZAŁE W PARTYKULARNYM PRAWIE POLSKIM}

W ostatnim czasie również w Polsce do seminariów duchownych zgłaszają się kandydaci w wieku przynajmniej 30 lat, którzy często porzucają drogę kariery zawodowej czy naukowej i odkrywają w sobie dar powołania. Każdego roku do seminarium zgłaszają się kandydaci w wieku powyżej 35 roku życia i należy zadać pytanie, jak odnajdą się wśród współczesnych 20- 
-latków. Pomysłodawcą utworzenia takiego seminarium w Polsce był abp Grzegorz Ryś, obecny Metropolita Łódzki, który jako Rektor Wyższego Seminarium Duchownego Archidiecezji Krakowskiej i Przewodniczący Konferencji Rektorów Wyższych Seminariów Duchownych Diecezjalnych i Zakonnych, zainicjował dyskusję na ten temat [Mraczek 2018, 235].

W dniu 11 czerwca 2014 r. Konferencja Episkopatu Polski podjęła decyzję o powołaniu Ogólnopolskiego Seminarium dla Starszych Kandydatów do Święceń z siedzibą w Krakowie, które potocznie nazywane jest „Seminarium 35+”. Dnia 9 września 2014 r. Kongregacja ds. Duchowieństwa wydała dekret aprobujący erygowanie Ogólnopolskiego Seminarium dla Starszych Kandydatów do Święceń oraz zatwierdziła ad experimentum statut tego seminarium na trzy lata, a 1 lipca 2017 r. Kongregacja przedłużyła ważność statutu na kolejne dwa lata [tamże, 236]. Seminarium ma charakter międzydiecezjalny i obejmuje wszystkie diecezje obrządku łacińskiego w Polsce. Kandydaci po odbyciu formacji i przyjęciu święceń swoją posługę będą wypełniać we własnych diecezjach.

\subsection{Miejsce formacji}

Seminarium powinno być uprzywilejowanym miejscem formacji kapłańskiej. Jest ono w Kościele kontynuacją wspólnoty apostołów zgromadzonych wokół Jezusa, którzy słuchają Jego słów, przygotowują się do przeżycia Paschy, oczekują na dar Ducha, aby mogli podjąć powierzoną sobie misję (PDV 60). Seminarium duchowne pozostaje żywym świadectwem, że w każdym pokoleniu Pan Jezus wzywa i zaprasza do pójścia za Nim i poświęcenia Mu swojego życia [Giemza 2007, 77].

Jako miejsce formacji dojrzałych kandydatów do kapłaństwa wybrano Kraków. Alumni studiowali na Wydziale Teologicznym Uniwersytetu Papieskiego w Krakowie razem z klerykami seminarium krakowskiego, a zamieszkiwali w dawnej szkole ojców cystersów w Nowej Hucie [Zimończyk 2018]. Po pięciu latach w 2019 r. seminarium zostało przeniesione do Łodzi i mieści się w wydzielonej części gmachu Wyższego Seminarium Archidiecezji Łódzkiej ${ }^{8}$. Abp Ryś tłumacząc tę decyzję wskazał: „Trzeba powiedzieć, że realia funkcjonowania tego Seminarium w Krakowie były bardzo trudne. Kraków jest z jednej strony miejscem cudownym dla takiej insty-

\footnotetext{
${ }^{8}$ Seminarium 35+ przeniesiono $z$ Krakowa do Eodzi, https://ekai.pl/seminarium-35przeniesiono-z-krakowa-do-lodzi/ [dostęp: 10.04.2020].
} 
tucji z uwagi na wielotwarzowy i wielowątkowy świat akademicki - to sprzyja, ale $\mathrm{z}$ drugiej strony warunki życiowe były tam dosyć uciążliwe -

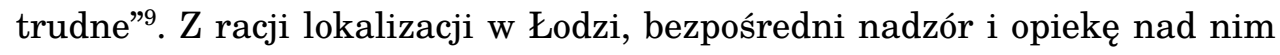
pełni Arcybiskup Metropolita Łódzki z zachowaniem kompetencji Konferencji Episkopatu Polski.

\subsection{Wymogi przyjęcia do seminarium}

Wymogiem koniecznym przyjęcia do seminarium jest powołanie kapłańskie będące dobrowolną odpowiedzią człowieka na głos Boga. W każdym powołaniu istnieją dwa nierozłączne elementy: wolny dar Boga oraz odpowiedzialna wolność człowieka [Sitarz 2013, 1083]. Powołanie jest darem Bożej łaski otrzymanym za pośrednictwem Kościoła, w Kościele i dla służby Kościołowi. Samo pragnienie bycia kapłanem nie wystarczy, alumn nie ma prawa do otrzymania święceń.

„Seminarium 35+” jest przeznaczone dla kandydatów w wieku od 35 do 60 lat, którzy legitymują się świadectwem maturalnym oraz są stanu wolnego (kawalerowie i wdowcy). Z formalnego punktu widzenia nie ma przeszkód, aby przyjąć kandydata, który uzyskał stwierdzenie nieważności małżeństwa, jednak każdorazowo wymaga to poważnego rozeznania. Kandydatów do seminarium zgłaszają biskupi diecezjalni, a decyzję o przyjęciu podejmuje rektor. Należy zauważyć, że biskup nie jest zmuszony do wysłania kandydata do „Seminarium 35+”, nie jest to obowiązek, ale propozycja. Rektor może skierować kandydata na okres propedeutyczny w jego macierzystej diecezji, a po jego ukończeniu następuje decyzja o przyszłości kandydata. Możliwa jest również sytuacja rozpoczęcia przez kandydata formacji w „Seminarium 35+” bez odbycia annus propedeuticus ${ }^{10}$.

Każdy z kandydatów powinien przedstawić następujące dokumenty: świadectwo chrztu i bierzmowania, pisemne skierowanie udzielone przez własnego biskupa diecezjalnego, świadectwo dojrzałości i ewentualnie inne dokumenty potwierdzające wykształcenie pomaturalne i wyższe, życiorys, w przypadku kandydatów związanych wcześniej małżeństwem - dokument o ustaniu małżeństwa (akt zgonu małżonki lub prawomocny wyrok

\footnotetext{
${ }^{9}$ Zob. https://deon.pl/kosciol/jedyne-takie-seminarium-duchowne-w-polsce-przenosi -sie-z-krakowa-do-lodzi,528743 [dostęp: 10.04.2020].

${ }^{10} \mathrm{Na}$ podstawie wywiadu ks. Pawła Kłysa z abp. Grzegorzem Rysiem. Pełna treść wywiadu: https://www.youtube.com/watch?v=ogofFCeQn9Q [dostęp: 10.04.2020].
} 
stwierdzający nieważność małżeństwa), świadectwo zdrowia, podanie oraz opinię proboszcza lub odpowiedniego duszpasterza ${ }^{11}$.

\subsection{Struktura organizacyjna i odpowiedzialni za formację}

Każde wyższe seminarium duchowne utworzone przez kompetentną władzę kościelną otrzymuje w Kościele osobowość prawną, czyli staje się podmiotem wszystkich praw i obowiązków zgodnych $\mathrm{z}$ jego naturą ${ }^{12}$. Przyznanie seminarium duchownemu osobowości prawnej ma znaczenie nie tylko $\mathrm{w}$ stosunkach wewnątrzkościelnych, ale również $\mathrm{w}$ relacjach $\mathrm{z}$ władzami państwowymi (ad extra). „Seminarium 35+” jest autonomiczne i działa pod nadzorem Konferencji Episkopatu Polski.

Wspólnota wychowawcza seminarium jest skupiona wokół osób odpowiedzialnych za formację: rektora, kierownika lub ojca duchownego, przełożonych i wykładowców. Wszyscy oni powinni czuć się ściśle złączeni z biskupem, którego reprezentują z różnych tytułów i w różny sposób (PDV 66).

Również w „Seminarium 35+” istnieje grupa formatorów. Seminarium jest autonomiczne, dlatego też ma swojego rektora, którym jest ks. dr hab. Sławomir Szczyrba. Z racji miejsca, w jakim zostało ulokowane seminarium, tj. wyodrębniona część Łódzkiego Seminarium Duchownego, zdecydowana część formatorów będzie taka sama w obu seminariach.

\subsection{Przebieg formacji seminaryjnej}

Co do zasady okres formacji kandydata do kapłaństwa powinien trwać nie mniej niż sześć lat (kan. 250). Ustawodawca powierzył biskupowi kompetencje dyskrecjonalne polegające na skróceniu czasu formacji w seminarium alumnów ze względu na specjalne okoliczności, jednak nie krócej niż do czterech lat [Krukowski 2005, 59]. Jest sprawą oczywistą, iż możliwość skrócenia okresu pobytu seminarzystów w seminarium należy rozważać jako wyjątkową i tylko w szczególnie uzasadnionych przypadkach [Selejdak 2011, 113]. Najczęściej będą to alumni, którzy przed wstąpieniem do seminarium ukończyli humanistyczne studia wyższego stopnia oraz osoby, które stosunkowo późno odkryły swoje powołanie.

W „Seminarium 35+” każdy z alumnów ma indywidualny tok studiów, który zależy od przebytej dotychczas drogi życiowej. Formacja w semina-

${ }^{11}$ Zob. https://web.archive.org/web/20181027231955/http://35plus.cba.pl/dokumenty. html [dostęp: 10.04.2020].

${ }^{12}$ Kodeks Prawa Kanonicznego z 1917 r. zaliczał seminarium do osób moralnych. 
rium duchownym przebiega na czterech płaszczyznach. Dzieje się tak dlatego, że do pełnienia misji kapłana we współczesnym świecie potrzebny jest jego integralny i całościowy rozwój. Rozwój musi dotykać sfery osobowościowej, duchowej, intelektualnej i pastoralnej każdego alumna.

Formacja ludzka za punkt wyjścia bierze dotychczasowe życiowe doświadczenie kandydatów, ze szczególnym uwzględnieniem dotychczasowych umiejętności i talentów. Dojrzałe spojrzenie na zawiłości życia codziennego i problemy społeczne może być wielkim atutem kleryków, którzy w późniejszym okresie życia odkryli powołanie do kapłaństwa [Zimończyk 2018]. Mając na uwadze wiek kandydatów raczej nie występują problemy natury dyscyplinarnej, chociaż człowiek, który ma już za sobą 40 czy 50 lat życia, bardzo często ma swoje nawyki i przyzwyczajenia, które trudno niekiedy zmienić.

Formacja duchowa odbywa się pod kierunkiem ojca duchownego oraz spowiedników i podobnie jak w pozostałych płaszczyznach jest zindywidualizowana. Również w tym wymiarze klerycy mają swoje przyzwyczajenia, które trudno jest im zmienić. Często ważniejsze są dla nich ich prywatne modlitwy od modlitwy wspólnotowej czy liturgicznej [Mraczek 2018, 238]. Mimo, iż święcenia takich kandydatów będą miały miejsce w ich diecezjach macierzystych i później właśnie tam będą posługiwać, to posługi takie jak lektorat czy akolitat przyjmują w „Seminarium 35+”.

Sporym testem zarówno dla kandydatów, jak i wykładowców może okazać się formacja intelektualna. Przede wszystkim chodzi tu o wiek alumnów oraz różnice w posiadanym wykształceniu. Niektórzy edukację zakończyli zdaniem matury, część ukończyła studia świeckie na różnych kierunkach, dlatego też formacja intelektualna jest zindywidualizowana i dobierana dla każdego alumna.

Formacja pastoralna w części teoretycznej przebiega w budynku seminarium $\mathrm{w}$ ramach stosownych zajęć, natomiast praktyki odbywają się już w diecezjach, skąd pochodzą kandydaci, według tradycji danego Kościoła partykularnego. Ma to na celu głębsze zintegrowanie alumna $\mathrm{z}$ jego Kościołem partykularnym, w którym będzie służyć po święceniach. Jak w każdej płaszczyźnie formacji, tak również na etapie duszpasterskim, należy indywidualnie podejść do każdego z kandydatów.

W roku akademickim 2020/2021 - 8 kandydatów otrzymało rekomendację swoich biskupów, a 6 jest na dalszych etapach formacji. 


\section{PODSUMOWANIE}

Podsumowując należy wskazać, że Seminarium dla Starszych Kandydatów do Święceń stanowi nowość w Polsce. Mając na uwadze coraz większą liczbę późniejszych powołań, erygowanie takiego seminarium jest bardzo cenną inicjatywą. Równocześnie należy mieć na uwadze malejącą z każdym rokiem liczbę powołań kapłańskich, dlatego „Seminarium 35+” jest wielkim dobrem dla Kościoła w Polsce. Doświadczenie osób starszych może okazać się bezcenne w wielu sytuacjach, z którymi młody ksiądz po święceniach nie miał styczności (szczególnie chodzi tu o tych, którzy przed wstąpieniem do seminarium byli w związku małżeńskim). Inicjatywa utworzenia seminarium dla starszych powołań odpowiada na potrzeby oraz problemy współczesnego społeczeństwa. Bez wątpienia kapłani z większym doświadczeniem życiowym ubogacą każdą diecezję. Takie seminarium jest szansą dla mężczyzn, którzy dotychczas bezskutecznie ubiegali się o przyjęcie do własnego seminarium diecezjalnego [Zimończyk 2018].

\section{PIŚMIENNICTWO}

Baniak, Józef. 2012. Powołania do kapłaństwa i do życia zakonnego $w$ Polsce $w$ latach 1900-2010. Studium socjologiczne. Poznań: Wydawnictwo Naukowe Wydziału Nauk Społecznych Uniwersytetu im. Adama Mickiewicza.

Bielas, Lucjan. 2019. „Ojciec Duchowny odpowiada...” http://www.35plus.cba.pl/ojciecduchowny-odpowiada....html [dostęp: 14.02.2020].

Cito, Davide. 2004. „The Formation of Clerics.” W Exegetical Commentary on the Code of Canon Law, t. II/1, red. Ángel Marzoa, Jorge Miras, i Rafael Rodríguez-Ocaña. English language edition. General editor Ernest Caparros. Review coordinator Patrick Lagges, 220. Montreal-Downers Growe: Wilson \& Lafleur, Midwest Theological Forum.

Gałązka, Włodzimierz. 2008. „Formacja seminaryjna w świetle nauczania biskupa Mikołaja Sasinowskiego." Studia Teologiczne t. 26, 273-88.

Giemza, Bogdan. 2007. „Formacja kapłańska w nauczaniu Ratzingera/Benedykta XVI.” Studia Salvatoriana Polonica 1:77-94.

Hałas, Stanisław. 2014. „UWierzyliśmy miłości» (1 J 4,16). Biblijny obraz formacji sercańskiej w świetle nauczania bł. Jana Pawła II.” Sympozjum 26, nr 1:9-18.

Haręzga, Stanisław. 1994. „Ewangelia powołania J 1, 35-42 według Adhortacji Pastores Dabo Vobis.” Ateneum Kapłańskie 86, z. 1:83-97.

Jakubiak, Tomasz. 2014. „Późne powołania kapłańskie.” Prawo Kanoniczne 57, nr 4: 89-110.

Krukowski, Józef. 2005. „Formacja duchownych.” W Komentarz do Kodeksu Prawa Kanonicznego. T. II/1: Księga II. Lud Boży. Część I. Wierni chrześcijanie. Część II. Ustrój hierarchiczny Kościoła, red. Józef Krukowski, 55-84. Poznań: Pallottinum. 
Latusek, Paweł. 1967. „Odpowiedzialność całego Ludu Bożego za powołania kapłańskie.” Ateneum Kapłańskie 70, z. 1-2:39-50.

Martin, James. 2015. Jezus. Przekład Krzysztof Jasiński, i Anna Wawrzyniak. Poznań: Wydawnictwo Święty Wojciech.

Mraczek, Michał. 2018. „Seminarium duchowe jako miejsce duszpasterstwa formacyjnego w świetle Pastores dabo vobis.” Rozprawa doktorska. Uniwersytet Papieski Jana Pawła II.

Pastewski, Przemysław. 2015. „Czym charakteryzuje się powołanie kapłańskie w rozumieniu św. Jana Pawła II.” Civitas et Lex 4 (8):79-89.

Postawa, Andrzej. 2005. Powołania kapłańskie w Towarzystwie Salezjańskim w Polsce. Studium socjologiczno-pastoralne. Kraków: Zakład Wydawniczy NOMOS.

Selejdak, Ryszard. 2011. „Aktualne aspekty formacji przyszłych kapłanów.” Teologia i Człowiek 17:111-36.

Sitarz, Mirosław. 2013. „Wymogi stawiane kandydatom do święceń według Kodeksu Prawa Kanonicznego z 1983 r. i wytycznych dykasterii Kurii Rzymskiej.” W Abiit, non obitt. Księga poświęcona pamięci Księdza Profesora Antoniego Kościa SVD, red. Antoni Dębiński, Piotr Stanisz, Tomasz Barankiewicz, i in., 1083-1097. Lublin: Wydawnictwo KUL.

Starzak, Grażyna. 2013. „Seminarium późnych powołań.” https://dziennikpolski24.pl/ seminarium-poznych-powolan/ar/3285030 [dostęp: 11.02.2020].

Tahhan, Antoinne. 2018. „Formacja pasterza dającego życie za owce - głos kapłana z Syrii." W Jakie seminarium diecezjalne na nasze czasy? Materiały $z$ międzynarodowego sympozjum 16-17 kwietnia 2018 r., red. Jan Miczyński, 134-40. Lublin: Wydawnictwo Muzyczne Polihymnia.

Wosiński, Józef. 1967. „Teologia powołania do kapłaństwa. Szkic historyczno-sprawozdawczy." Ateneum Kaptańskie 59, z. 1-2 (348-349):29-38.

Zimończyk, Łukasz. 2018. „Seminarium dla starszych mężczyzn - jak to działa?” https://www.gosc.pl/doc/4935379.Seminarium-dla-starszych-mezczyzn-jak-to-dziala [dostęp: 10.04.2020].

\section{Późne powołania kapłańskie w Kodeksie Prawa Kanonicznego z 1983 roku i partykularnym prawie polskim}

\section{Streszczenie}

W artykule zostały opisane późne powołania kapłańskie. Autor wskazał, jak to zagadnienie zostało przedstawione w Kodeksie Prawa Kanonicznego z 1983 r. oraz jak wygląda formacja dojrzałych kandydatów do kapłaństwa w partykularnym prawie polskim. W pierwszej części artykułu określono, czym jest powołanie oraz opisano powołanie pierwszych uczniów Jezusa. Mając na uwadze wzrost powołań osób niebędących w młodym wieku została również wskazana troska o kandydatów do kapłaństwa w wieku dojrzałym. Autor podkreślił, że szczególnie zobowiązani do opieki o takie osoby są biskup oraz kapłani. Mają oni dbać o ich odpowiednią formację oraz udzielać im odpowiedniej pomocy z uwzględnieniem indywidualnej sytuacji każdego z nich. W drugiej części artykułu została przedstawiona instytucja Ogólnopolskiego Seminarium dla Starszych Kandydatów do Święceń zwanego „Seminarium 35+”, które znajduje się w Łodzi. Autor opisał warunki przyjęcia do seminarium, strukturę organizacyjną oraz 
przebieg formacji seminaryjnej uwzględniając 4 płaszczyzny formacji: ludzką, duchową, intelektualną oraz pastoralną.

Słowa kluczowe: późne powołanie; seminarium; proces formacji; Kodeks Prawa Kanonicznego z 1983 r.; prawo partykularne

\section{Late Priest Vocations in the 1983 Code of Canon Law and Particular Polish Law}

\section{Summary}

The study explores the late priestly vocations. The author indicated how this issue was set out in the 1983 Code of Canon Law and what is the status of the formation of mature candidates for sacred mysteries in the particular Polish law. The first part of the paper defines the concept of vocation and the call of the first disciples was described. Bearing in mind the increase in the vocations of mature candidate for priesthood concern for candidates for the priesthood was also placed. The author emphasized that the bishop and priests are particularly obliged to care for mature candidate. They are to ensure their proper formation and that they provide them with appropriate help, taking into account the individual situation of each of them. The second part of the article shows the institution of the National Seminar for Older Candidates for Holy Orders called "Seminary 35+", which is founded in Łódź. The author described the requirement to join the seminary, the organizational structure and the process of seminary formation, taking into account the principal dimensions of formation: human, spiritual, intellectual, and pastoral.

Key words: late vocation; seminary; formation process; the 1983 Code of Canon Law; particular law

Information about Author: Wолсіесн Pотоскі, PH.D. - District Court in Warsaw; e-mail: wojciech.b.potocki@gmail.com; https://orcid.org/0000-0002-9390-6519 